\title{
Everyday Life in the Muslim Middle East
}

Donna Lee Bowen and Evelyn A. Early, eds.

Bloomington, IN: Indiana University Press, 2002, 2d ed. 411 pages.

Everyday Life in the Muslim Middle East, now in its second edition, is a collection of songs, articles, poems, and letters, as well as manuscripts, related to life in the Muslim Middle East. The authors, a mix of well- 
known (and less well-known) scholars and writers from the Middle East and the West, seek to give readers an intimate look at the everyday life of the region's Muslim inhabitants in the hopes of addressing and dispelling some common stereotypes.

Everyday Life is divided into five sections, each of which contains various essays, stories, and so on. Section One focuses on family life, birth, adolescence, marriage, and death. The first piece is Erika Friedl's collection of traditional songs from southwestern Iran about such events as childbirth and marriage. Susan Schaefer Davis examines how childrearing has changed in north-central Morocco from the 1970s to the present. In the next story, "Explosion," Lebanese journalist Emily Nasrallah depicts the tragedy of a young girl who parts from her mother at a supermarket and dies in an explosion. Next is an essay by Margaret A. Mills about an arranged marriage in Afghanistan. Jenny B. White ("Two Weddings") compares and contrasts traditional and modern Turkish weddings. In "Editing al-Fajr: A Palestinian Newspaper in Jerusalem," Bishara Bahbah talks about the experiences and challenges he faced as the editor-in-chief of the Jerusalem-based al-Fajr. Next is an excerpt from popular Moroccan novelist Driss Chraibi's "The Son's Return," in which he discusses the generation gap when a Moroccan immigrant to the West returns to visit his grandfather.

Section Two, which discusses gender relations and roles, begins with Angel Foster's interviews of Tunisian female university students regarding women's health and sexuality issues. Next is another article by Friedl, in which she highlights female attitudes toward marriage in Iran. Dawn Chatty looks at marriage and divorce for the Harasiis, and Christine Eickelman addresses the role of a petroleum-based economy and examines how oil wealth has impacted cultural conceptions of fertility in Oman. Ziba Mir-Hosseini discusses various case studies of marriage and divorce in Iran in her effort to produce a documentary on Iranian family law. Completing this section is Elizabeth W. Fernea's piece about her now-classic film "The Veiled Revolution," which discusses the revival of traditional Islamic attire among working Muslim women in a postIslamist Muslim world.

Section Three discusses other traditional institutions, such as the family or the mosque, and how they are educating their members to play a vital part in preserving a cultural heritage while simultaneously dealing with community issues and advancing their careers. "The Doum Tree of Wad Hamid" by Tayeb Salih, Sudan's most famous novelist, is a classic 
narrative of old and new townspeople adjusting to life in the Sudanese village of Wad Hamid. The next selection, by Donna Lee Bowen, examines the Muslim stance on abortion as it has been legalized in several Muslim countries and as more women quietly seek abortions.

Susan Ossman looks at beauty and fashion trends, and how much "looking good" matters to all of Casablanca's inhabitants. W. Stephen Howard's composition discusses the lives of teachers in the Middle East, and Diane Singerman analyzes family job networking in Cairo. The following essay, by Brian K. Barber, illustrates the political realities that shape pubescent experiences in Jerusalem and the West Bank. The concluding article, by Quintan Wiktorowicz, discusses Islamist activism in Jordan and, drawing attention away from the few radical Islamists so liked by the western media, focuses on the majority of moderate Islamists who desire the application of Muslim values in politics.

Section Four talks about religion's popular expression in the Middle East. Dale E. Eickelman discusses "Islamic reformation" and how individuals with training in the applied sciences have become the chief theoreticians of Islamic groups. Next, Kristina Nelson discusses the significance of sound and language when reciting the Qur'an and the importance of its meaning to many Muslims. Donna L. Bowen has two pieces, one looking at the importance of zakat and the other on the 'Id al-Adha celebrations. Michael E. Jansen, an American convert to Islam, describes the experience of performing hajj as an American. Anne H. Betteridge notes the differences between the pre- and post-Iranian revolutionary traditions of women visiting shrines in Shiraz, while Annabelle Bottcher discusses the role of devout Sunni women in Syria as religious scholars and teachers while simultaneously seeking to balance that role with domestic life. Last is Jon W. Anderson's essay on introducing the Internet to the Muslim world and disseminating religious ideas in cyberspace.

The last section focuses on the entertainment industry and the region's love for the arts. Evelyn A. Early discusses how historical dramas have flourished on Syrian television in the past decade, while also challenging state censorship. Walter Armbrust looks at television viewing during Ramadan in Egypt, and explains how religious activities are balanced with recreation. Kevin Dwyer critiques various Moroccan films as he looks at the struggling Moroccan film industry. Susan Slyomovics translates some of the stories of the Moroccan poet Salah El-Ouadie, who writes about prison life in the Middle East., and Steven C. Caton looks at Yemeni civil war poetry. The last selection in this anthology is Lila Abu- 
Lughod's essay on Egyptian Bedouin women's poems as expressions of their thoughts, feelings, and problems.

Overall, this new edition of Everydoy Life in the Muslim Middle East is an excellent addition to the literature on Middle East studies. The essays are accessible and convey a sense of ordinary life in the Muslim Middle East to a western reader. A concluding section that tied the themes together would have been useful.

Nazia Khandwala

Asian and Islamic Studies Major The University of 'Texas at Austin, Austin, Texas 